\title{
Inhibitory Effect of Antineoplaston A10 and AS2-1 on Human Hepatocellular Carcinoma
}

\author{
HIDEAKI TSUDA, AKIHIRO IEMURA* MICHIO SATA**, MASAFUMI UCHIDA ${ }^{\dagger}$, \\ KAZUNARI YAMANA ${ }^{\dagger \dagger}$ AND HIROSHI HARA ${ }^{\dagger \dagger}$ \\ Departments of Anesthesiology, Pathology*, Medicine ${ }^{* *}$, Radiology ${ }^{\dagger}$ and \\ Surgery ${ }^{\dagger \dagger}$, Kurume University School of Medicine, Kurume 830, Japan
}

Received for publication March 13, 1996

\begin{abstract}
Summary: Antineoplastons, first described by Burzynski, are naturally occurring peptides and aminoacid derivatives which control neoplastic growth. Antineoplaston A10 (3-phenylacetylamino-2,6-piperidinedione) is the first chemically identified antineoplaston and when it is administered orally it is hydrolysed in pancreatic juice to phenylacetylglutamine and phenylacetylisoglutamine in the ratio of 4 to 1 . These metabolites are water soluble and have antitumor effect, they are further degraded to phenylacetic acid. The mixture of phenylacetylglutamine and phenylacetylisoglutamine in the ratio of 4 to 1 was formulated as Antineoplaston A10 injectable formulation. The mixture of phenylacetylglutamine and phenylacetic acid in the ratio of 1 to 4 was also shown to have antitumor effect in tissue culture study, then formulated as Antineoplaston AS2-1. The reported cytostatic inhibitory effect of A10 on human hepatocellular carcinoma cells and differentiation inducing effect of AS2-1 on various tumor cells suggest potential benefit for the treatment of human hepatocellular carcinoma since this tumor recurs frequently despite initial successful treatment. We report here the effects of Antineoplaston A10 and AS2-1 on cell proliferation, cell morphology, cell cycle, and DNA in human hepatocellular carcinoma cell lines. Both agents inhibited cell proliferation and increased the number of cells in $G_{0}$ and $G_{1}$ phases and Antineoplaston AS2-1 induced apoptosis, we also describe our clinical experience of a hepatocellular carcinoma (HCC) patient whose tumor, after incomplete transcatheter arterial embolization (TAE) for a $7 \mathrm{~cm}^{*} 7 \mathrm{~cm} \mathrm{HCC}$, has been stable for more than 15 months during which time he has been taking Antineoplaston AS2-1 continuously without any serious adverse effects.
\end{abstract}

Key words: Antineoplaston A10, AS2-1, hepatocellular carcinoma, cytostasis, apoptosis

\section{Introduction}

Hepatocellular carcinoma (HCC) has become one of the leading causes of death from cancer in Japan. Despite of early detection, the prognosis of HCC is not yet satisfactory. Early small tumors can often be treated successfully by percuta-

Reprint requests to: Hideaki Tsuda, Department of Anesthesiology, Kurume University School of Medicine, 67 Asahi-machi, Kurume 830, Japan. Tel: 0942-35-3311(3607) Fax: 0942-37-1403 
neous ethanol injection therapy (PEIT), transcatheter arterial embolization (TAE), microwave coagulation necrosis ( $\mathrm{MCN}$ ), or surgery but recurrence is frequent, and often multicentric within a year (Nakao et al. 1991).

Anticancer therapy to prevent multiple recurrence in $\mathrm{HCC}$ requires the intrahepatic arterial infusion of chemotherapeutic agents. This procedure is often stressful to the liver which shows dysfunction because of underlying chronic hepatitis or cirrhosis. The efforts must be made to develop nontoxic, chemopreventive agents effective against such recurrence. Antineoplaston A10, the first chemically identified and synthesized antineoplaston, exhibits a chemopreventive effect against chemicals and virus induced tumor formation, as well as, an inhibitory effect on tumor growth (Burzynski, 1976; Burzynski and Hai, 1985; Eriguchi et al. 1988; Muldoon et al. 1988; Nishida et al. 1991).

Antineoplaston AS2-1, the degradation products of Antineoplaston A10, induces cell differentiation in the HL-60, erythroleukemia, malignant melanoma, and fibrosarcoma cells (Burzynski et al. 1986; Samid et al. 1991, 1992). Antineoplaston A10 and AS2-1 exert cytostatic action on tumor cells rather than cytotoxic. It thus appears that Antineoplaston A10 and AS2-1 may be of value in preventing recurrence in HCC.

Accordingly, we tested the effect of Antineoplaston A10 and AS2-1 on 6 human hepatocellular cell lines. We also describe our clinical experience of a HCC patient whose tumor has been stable for more than 15 months with Antineoplaston AS2-1 treatment after incomplete TAE was performed for a
$7 \mathrm{~cm} * 7 \mathrm{~cm} \mathrm{HCC.}$

\section{Materials and Methods}

\section{Cell lines and cell culture}

Six human hepatocellular carcinoma cell lines (KIM-1, KYN-1, KYN-2, KYN-3, HAK-1A, HAK-1B), established at the First Department of Pathology, Kurume University School of Medicine, were subjected to an in vitro study. The cells were maintained at $37^{\circ} \mathrm{C}$ in an atmosphere of $95 \%$ air and $5 \% \quad \mathrm{CO}_{2}$ in Dulbecco's modified Eagle's medium (Nissui Seiyaku Co., Tokyo, Japan) supplemented with $5 \%$ fetal bovine serum (Whitvineker Bioproducts, Walkersville, MD USA), 100 units/ml penicillin, $100 \mu \mathrm{g}$ /ml streptomycin (GIBCO, Chargin Falls, $\mathrm{OH}$ USA) as a basal medium.

Effect of Antineoplaston A10 and AS2-1 on cell proliferation

An appropriate number of cells from each cell lines was seeded on 96-well plastic plates (Falcon; Becton Dickinson Labware, Lincoln Park, NJ USA) and cultured with basal medium for one day. On the next day, the medium was exchanged for fresh medium containing various concentrations $(0,0.5,1.0,2.0$, $4.0,8.0 \mathrm{mg} / \mathrm{ml}$ ) of Antineoplaston $\mathrm{A} 10$ or AS2-1 (Burzynski Research Institute, Houston, Texas USA). The cells were cultured for 48 or $72 \mathrm{hs}$, and then MTT (3(4,5-dimethylthiazol-2-yl)-2,5-diphenyltetrazolium-2H-bromide) (Chemicon, Temecula, CA USA) was added to the medium in each well to give a final concentration of $250 \mu \mathrm{g} / \mathrm{ml}$ and the plates were incubated for $4 \mathrm{hs}$ at $37^{\circ} \mathrm{C}$. The supernatants were gently removed, 100 $\mu \mathrm{l} /$ well of $40 \mathrm{mM} \mathrm{HCL} /$ dimethylsulfoxide 
was added to dissolve the resulting pigment. Viable cell numbers were estimated by measuring the absorbance with an Easy Reader EAR 400 (SLT Lab Instruments, Saltzburg, Austria), with a test wavelength of $570 \mathrm{~nm}$ and a reference wavelength of $630 \mathrm{~nm}$.

\section{Analysis of cell morphology}

Cells were seeded on Lab-Tek tissue culture chamber slides (Miles Laboratories, Naperville, IL USA) and cultured with basal medium for one day. On the next day, the medium was exchanged for fresh medium containing Antineoplaston A10 ( $8 \mathrm{mg} / \mathrm{ml}$ ) or AS2-1 (2 and $4 \mathrm{mg} / \mathrm{ml}$ ). The cells were cultured for $72 \mathrm{hs}$. Then they were fixed in Carnoy's solution and stained with Hematoxylin-Eosin for microscopic study.

Analysis of cell cycle and DNA synthesis

Cells were seeded on a $60 \mathrm{~mm}$ plastic dish (Falcon) and cultured with basal medium for one day. On the next day, the medium was exchanged for fresh medium containing Antineoplaston A10 $(8 \mathrm{mg} / \mathrm{ml})$ or Antineoplaston AS2-1 (2, 4 $\mathrm{mg} / \mathrm{ml}$ ) and the cells were cultured for 72 hs. Cells were then labeled with $10 \mu \mathrm{M}$ bromo-2'-deoxyuridine (BrdU) at $37^{\circ} \mathrm{C}$ for $30 \mathrm{~min}$, washed with $\mathrm{PBS}, \mathrm{pH} 7.6$, detached with Trypsin-EDTA, and fixed with $70 \%$ cold ethanol at $4 \mathrm{C}$ overnight. After fixation, the cells were treated with $2 \mathrm{~N} \mathrm{HCL} / 0.5 \%$ Triton X 100 for 20 min to denature the double strand DNA and to lyses the cell membrane. After neutralization with $0.1 \mathrm{M} \mathrm{Na2B} 407 / \mathrm{PBS}$, $\mathrm{pH} 8.5$, the cells were washed with $0.5 \%$ Tween 20/PBS, incubated with $20 \mu \mathrm{l}$ antiBrdU antibody (Becton Dickinson
Immunocytometry Systems USA, San Jose, CA USA) for $30 \mathrm{~min}$ at room temperature, washed twice with $0.5 \%$ Tween 20/PBS, incubated for 20 min with $20 \mu \mathrm{l}$ fluorescein conjugated goat antimouse immunoglobulin (Becton Dickinson Immunocytometry Systems), and washed with PBS. Then DNA was stained with $5 \mu \mathrm{g} / \mathrm{ml}$ propidium iodide and flow cytometric analyses were performed with a FACScan (Becton Dickinson Immunocytometry System).

\section{Analysis of DNA}

KIM-1 and HAK-1A cells were seeded on $10 \mathrm{~cm}$ plastic dishes (Falcon) and cultured with basal medium for several days to subconfluence and medium was exchanged for fresh medium containing Antineoplaston A10 (8 mg/ml) or AS2-1 ( 2 and $4 \mathrm{mg} / \mathrm{ml}$ ) or for medium without Antineoplaston, and the cells were cultured for 72 hs. The cells were then harvested with a cell scraper and extraction of genomic DNA was performed with Sepa Gene (Sanko Junyaku Co., Ltd., Tokyo, Japan). The DNA was dissolved in Tris/EDTA buffer, and $20 \mu \mathrm{g}$ per lane of sample DNA or DNA molecular size marker (X174/Hae III digest) was electrophoresed in $1.6 \%$ agarose gel and visualized with ethidium bromide under UV illumination.

Clinical application of Antineoplaston AS2-1 in HCC patient

A 50-year-old male patient underwent TAE with Lipiodol, ADM for a $7 \mathrm{~cm} * 7 \mathrm{~cm}$ HCC located in right hepatic lobe. Three months later, dynamic CT disclosed early enhancement and low attenuation in the delay phase around the embolized area suggesting the growth of a viable 
tumor lesion. The patient again underwent TAE but a viable tumor lesion was still shown on dynamic CT. Four months later after this first TAE, he joined the Antineoplaston AS2-1 phase I study program which has been conducted at Kurume University Hospital with the approval of the Ethics Committee since 1988. He signed an informed consent form, after which, treatment with oral formulation of Antineoplaston AS2-1 $8 \mathrm{~g}$ $10 \mathrm{~g} /$ day was instituted. An echogram was taken every month and CT was performed every 3 months. Hematological, urological, and liver function tests were performed every 3 months. He was treated as an outpatient except for a one week admission for PEIT, this being undertaken to treat a small suspicious nodule that appeared on the echogram after 6 months continuous treatment with Antineoplaston AS2-1 8-10 g/day.

\section{Results}

\section{Effects on cell proliferation}

The optic density of the 6 HCC cell lines cultured for 48 or $72 \mathrm{hs}$ in medium containing Antineoplaston A10 (2, 4, $8 \mathrm{mg} / \mathrm{ml})$ or $\mathrm{AS} 2-1(0.5,1,2 \mathrm{mg} / \mathrm{ml})$ is shown in Fig. 1. Antineoplaston A10 and AS2-1 inhibited cell proliferation timeand dose-dependently in all 6 HCC cell lines. Antineoplaston AS2-1 inhibited cell proliferation markedly regardless of the degree of differentiation of hepatocellular carcinoma cell and no viable cells were found at an concentration of $8 \mathrm{mg} / \mathrm{ml}$ (data not shown). A concentration of $8 \mathrm{mg} / \mathrm{ml}$ of Antineoplaston A10 was required to inhibit cell proliferation in KIM-1, KYN-3, HAK-1A, and HAK-1B cells.

\section{Effects on cell morphology}

Many apoptotic cells characterized by cytoplasmic atrophy, nuclear contraction, and irregular aggregation of nuclear chromatin, were observed in HAK-1A, KIM-1, and HAK-1B cells treated by Antineoplaston AS2-1 at concentrations of 2 and $4 \mathrm{mg} / \mathrm{ml}$, apoptotic cells were not observed in cells treated with Antineoplaston $\mathrm{A} 10$ at $8 \mathrm{mg} / \mathrm{ml}$ (Fig. 2).

\section{Effects on cell cycle}

Antineoplaston A10 and AS2-1 reduced the BrdU uptake ratio and the number of cells in $\mathrm{G}_{2} / \mathrm{M}$ phase in KIM-1, KYN-1, KYN-2, and HAK-1A cells. Cells in the $\mathrm{D}_{1}$ region, not uptaking $\mathrm{BrdU}$ between $2 \mathrm{C}$ and 4C DNA contents, were observed in KYN-1 and HAK-1A cells with Antineoplaston AS2-1 at a concentration of $4 \mathrm{mg} / \mathrm{ml}$ (Fig. 3).

Agarose gel electrophoresis of DNA from KIM-1 and HAK-1A cells showed DNA fragmentation with ladder in cells treated with Antineoplaston AS2-1 at concentrations of both 2 and $4 \mathrm{mg} / \mathrm{ml}$ (Fig. 4), no DNA fragmentation was observed in the cells treated with Antineoplaston $\mathrm{A} 10$ at $8 \mathrm{mg} / \mathrm{ml}$.

\section{Dynamic CT findings in the patient during the clinical course}

The viable part of the HCC lesion, high in early phase and low in delay phase attenuating lesion around embolized area, was recognized on dynamic CT taken 3 months after the first TAE. It disappeared gradually shown in the CT findings 13 and 20 months after the patient had begun treatment with Antineoplaston AS2-1 (Fig. 5). 

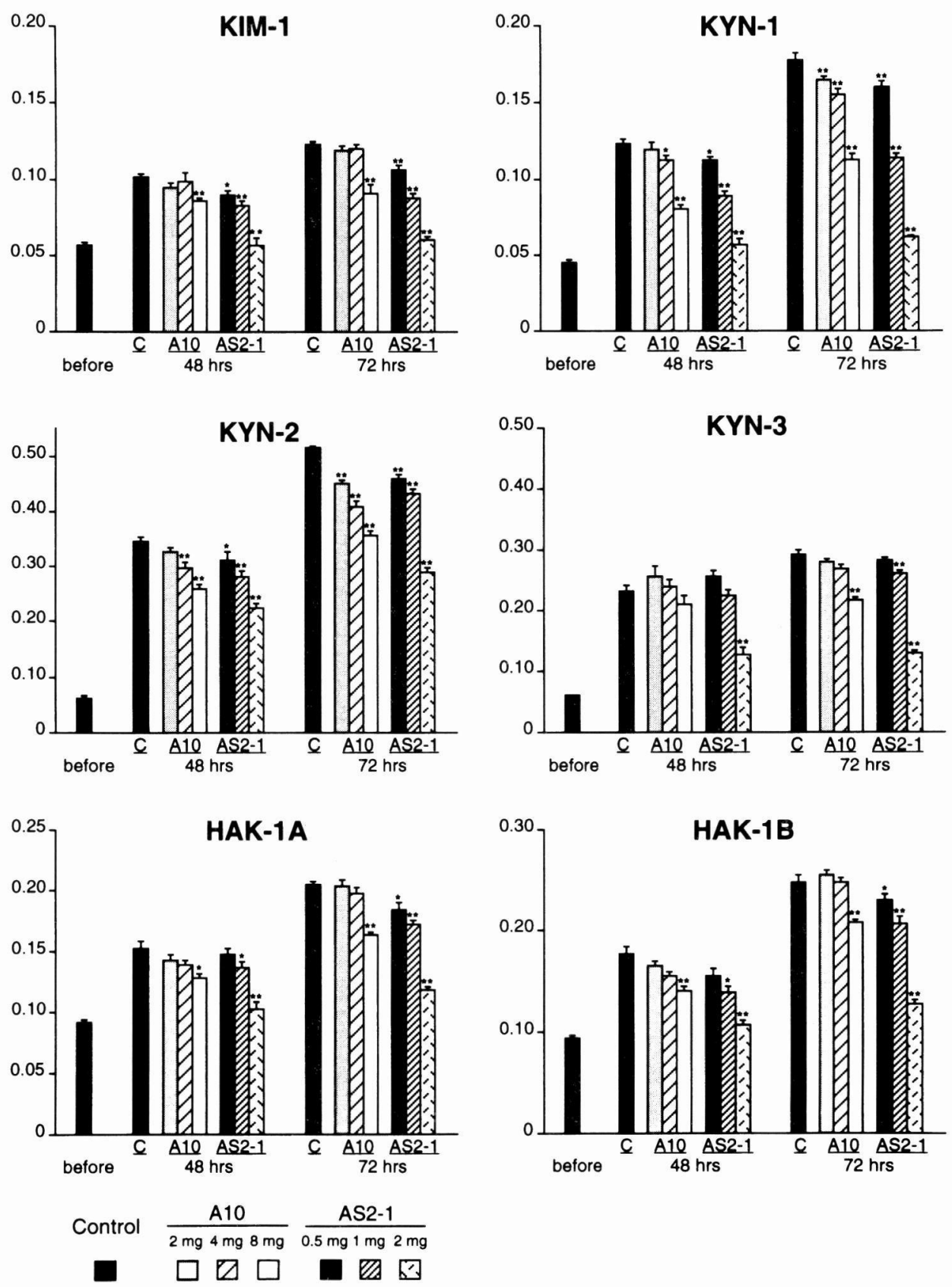

Fig. 1. Optic Density in MTT assay for KIM-1, KYN-1, KYN-2, KYN-3, HAK-1A, HAK-1B hepatocellular carcinoma cells incubated for 48, 72 hs with Antineoplaston A10 at concentrations of $2 \mathrm{mg} / \mathrm{ml}(\square), 4 \mathrm{mg} / \mathrm{ml}(\square), 8 \mathrm{mg} / \mathrm{ml}(\square)$ and with Antineoplaston AS2-1 at

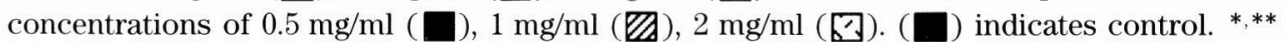
represent $\mathrm{p}<0.05, \mathrm{p}<0.01$ vs corresponding for control in each time points (Mann-Whitney $\mathrm{U}$ test). Antineoplaston A10 and AS2-1 inhibited cell growth dose-dependently. 

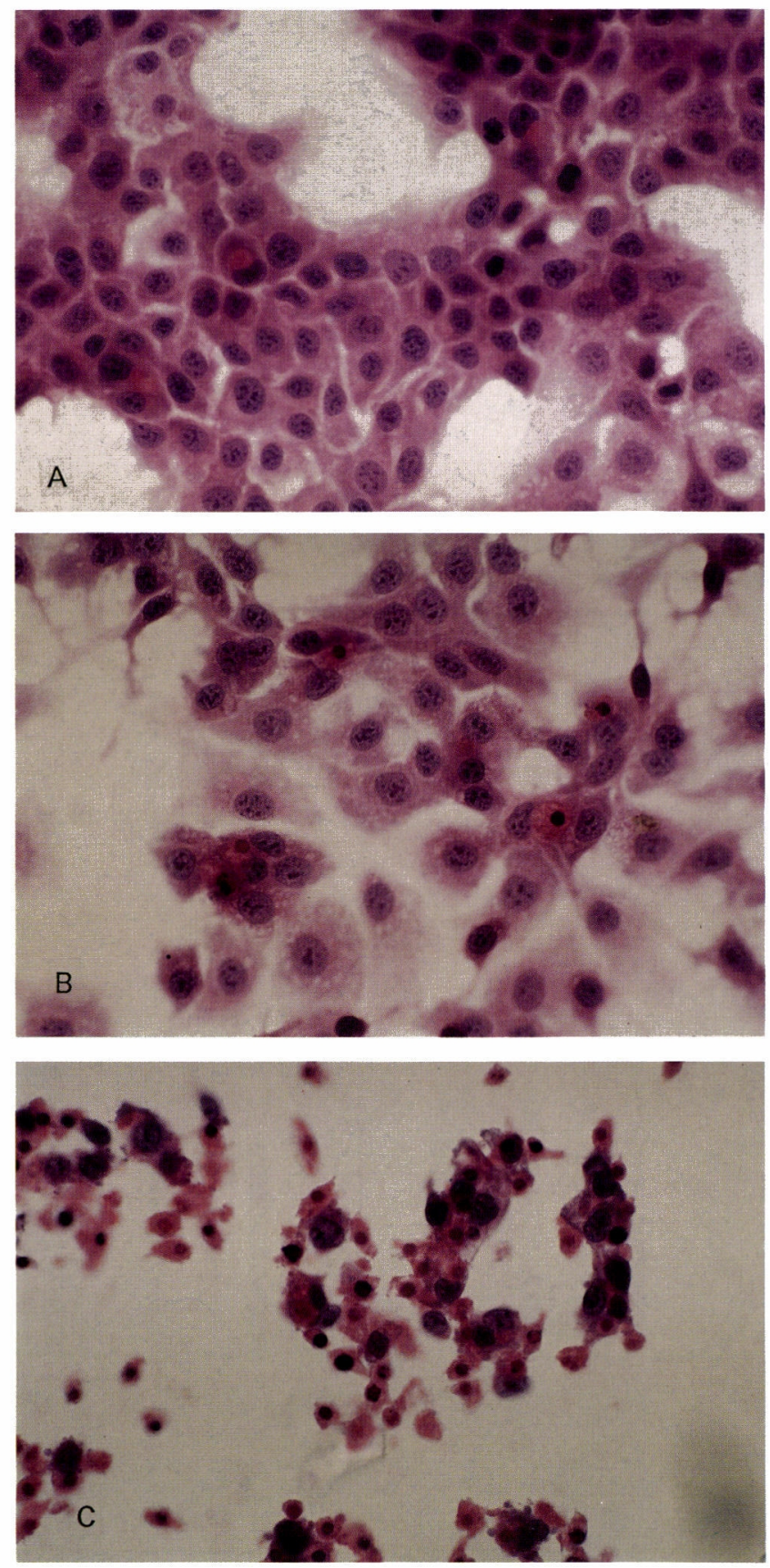

Fig. 2. H. E. stained KIM-1 hepatocellular carcinoma cells treated with Antineoplaston AS2-1 at concentrations of $2 \mathrm{mg} / \mathrm{ml} \mathrm{(B),} 4 \mathrm{mg} / \mathrm{ml}$ (C) for $72 \mathrm{hs}$. A indicates control. Apoptotic cells were observed in AS2-1 treated cells. 


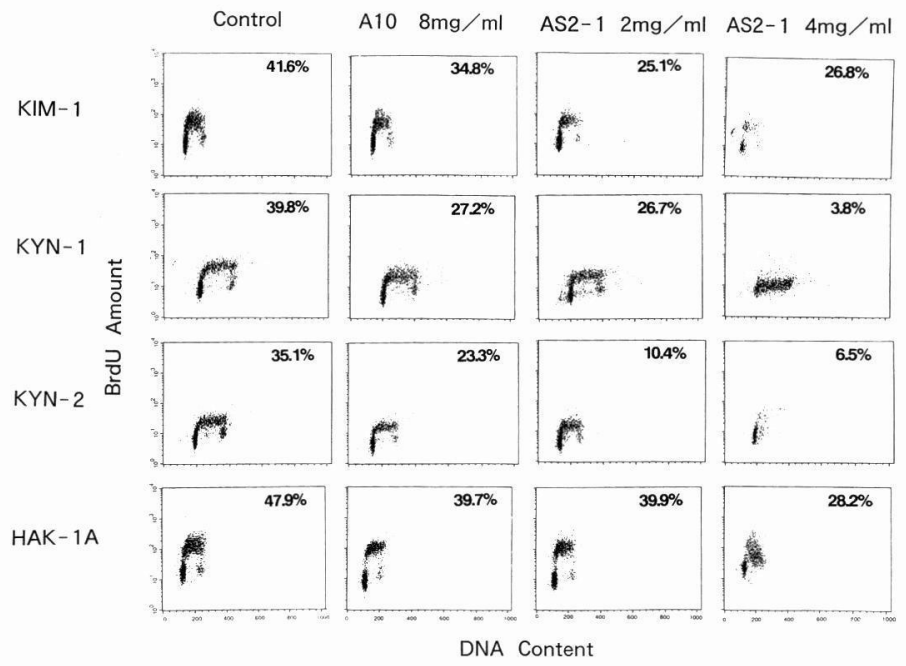

Fig. 3. Double stained flowcytometry of KIM-1, KYN-1, KYN-2, HAK-1A hepatocellular carcinoma cells treated with Antineoplaston A10 at concentration of $8 \mathrm{mg} / \mathrm{ml}$ and Antineoplaston AS2-1 at concentrations of $2,4 \mathrm{mg} / \mathrm{ml}$ for $72 \mathrm{hs}$. Number in \% indicates BrdU uptake. Antineoplaston A10 and AS2-1 reduced BrdU uptake ratio and number of cells in G2/M phase.

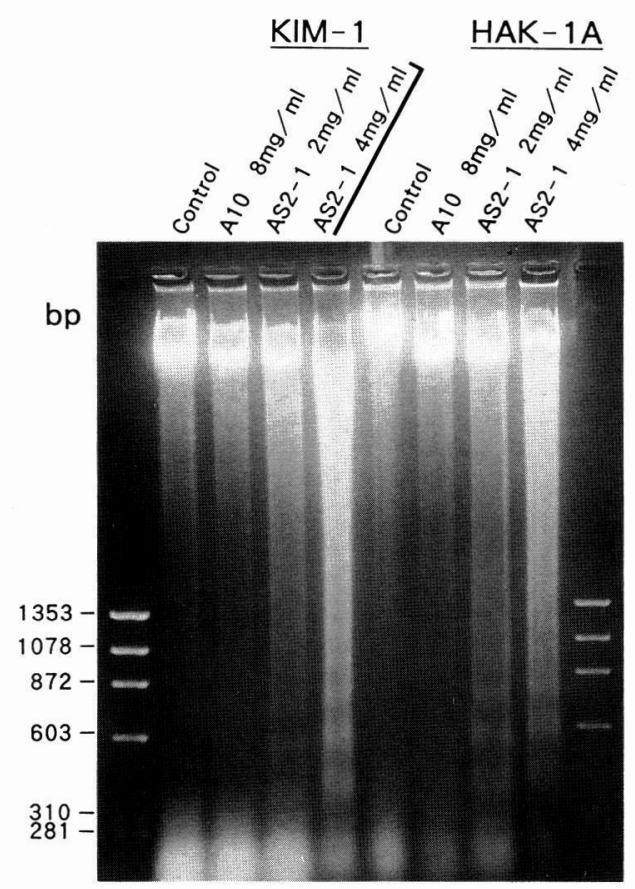

Fig. 4. Electrophoresed DNA of KIM-1, HAK-1A cells treated with Antineoplaston A10 at concentration of $8 \mathrm{mg} / \mathrm{ml}$ and Antineoplaston AS2-1 at concentrations of $2,4 \mathrm{mg} / \mathrm{ml}$ for $72 \mathrm{hs}$. Number indicates DNA molecular size marker. DNA fragmentation with ladder was observed in Antineoplaston AS2-1 treated cells. 

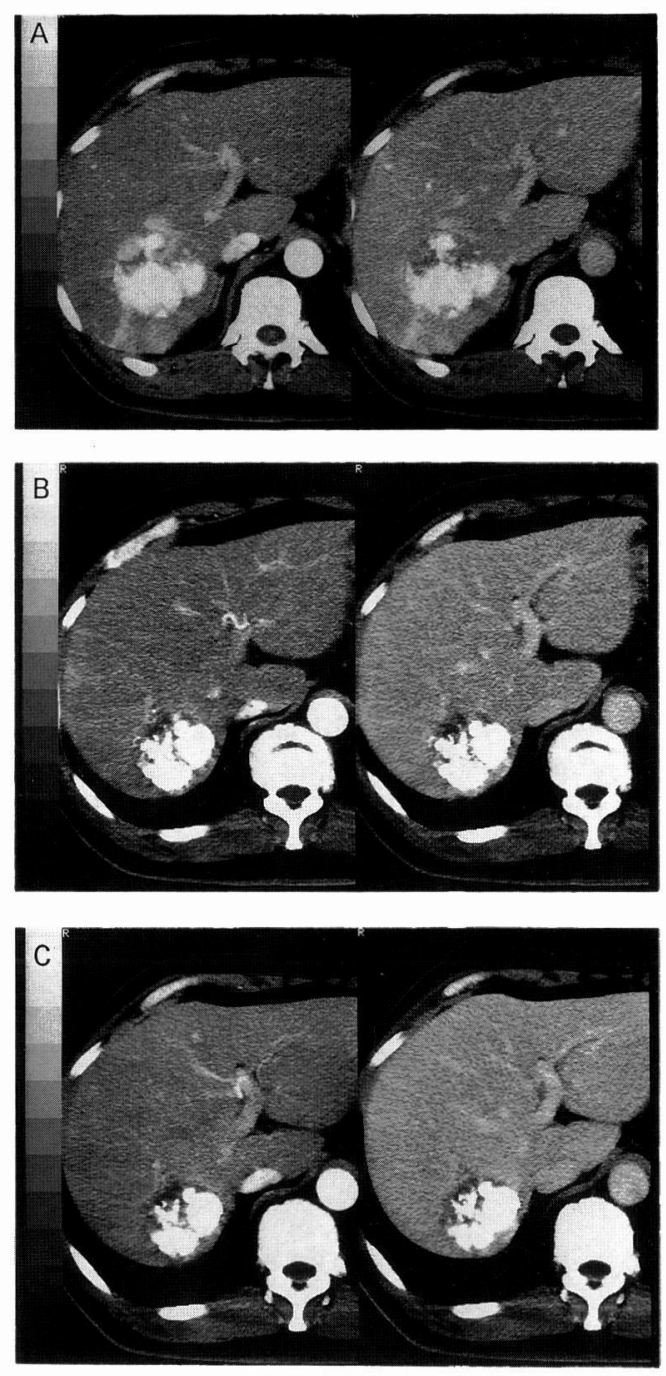

Fig. 5. Early and late phases of dynamic CT of liver of a hepatocellular carcinoma patient who had received Antineoplaston AS21 treatment. CT taken 3 months after the first incomplete TAE (A), CT taken 13 months after TAE (B), CT taken 20 months after TAE (C). A gradual reduction of viable lesion was observed.

\section{Discussion}

Hepatocellular carcinoma (HCC) is becoming a major problem in Japan (Okuda et al. 1987; Tanaka et al. 1990; Unoura et al. 1993). There is no doubt that early detection of a small solitary HCC by advanced diagnostic technology makes local approach such as PEIT, MCN, TAE, and surgery possible and contributes to better prognosis of this disease. However, even the patients treated in the early stage often show recurrence or multiple intrahepatic metastases (Ikeda et al. 1991; Nakao et al. 1991). This situation requires the intrahepatic arterial infusion of chemotherapeutic agents, these induce liver dysfunction since hepatocytes are essentially vulnerable to toxic agents and since chronic hepatitis and liver cirrhosis is almost always associated with HCC. Many patients in the terminal stage of this disease suffer from hepatic failure caused both by invasive tumors and by treatment with toxic agents. The development of less toxic agents that can prevent recurrence or multiple intrahepatic metastases after PEIT, TAE, MCN and surgery is crucial for overcoming this miserable situation.

Antineoplastons, naturally occurring peptides and aminoacid derivatives that control neoplastic growth, were first described by Burzynski in 1976. Antineoplaston A10 is the first of the antineoplastons to be chemically identified (Burzynski and Hai, 1985). Hendry speculated in a stereospecific study that Antineoplaston A10 (3-phenylacetylamino2,6-piperidinedione) could intercalate between base pairs of DNA and predicted that this agent would have a 
chemopreventive effect against carcinogens (Hendry and Muldoon,1987). Several authors have since reported the chemopreventive effect of this compound against various kinds of carcinogens (Eriguchi et al. 1988; Muldoon et al. 1988). Antineoplaston A10, when administered orally, is hydrolysed and degraded, to phenylacetylglutamine, phenylacetylisoglutamine, phenylacetic acids, glutamic acids.

A mixture of phenylacetylglutamine and phenyl acetic acid in the ratio of 1 to 4 (Antineoplaston AS2-1) was confirmed to have a antineoplastic and cell differentiating activities. Samid reported that Antineoplaston AS2-1 and phenylacetate, one of active components in Antineoplaston AS2-1, induced cell differentiation in erythroleukemia, fibrosarcoma, and malignant melanoma cells. (Samid et al. 1991, 1992). In our study, Antineoplaston A10 and AS2-1 exhibited dose- and timedependent inhibitory effects on cell proliferation in all 6 HCC cell lines tested; both agents increased the cell population in $G_{0}$ and $G_{1}$ phases and reduced that in $S$ phase, suggesting that they inhibited cell proliferation by arresting cell growth and not by destroying cells. The increase in cells in $\mathrm{D}_{1}$ region with Antineoplaston AS2-1 treatment indicates that these cells were about to become apoptotic. The presence of apoptotic cells in the morphological study and the DNA fragmentation in the Antineoplaston AS2-1 treated cells would suggest that these cells stopped growing and died from apoptosis. Antineoplaston A10 inhibited cell proliferation but did not induced apoptosis. The difference between Antineoplaston A10 and AS2-1 is that AS2-1 contains phenyl- acetic acid. The role played by phenylacetic acid in inducing cell differentiation or apoptosis is unclear. Liau and Burzynski (1986) have speculated that the hypomethylation of nucleic acids induced by phenylacetylglutamine and phenylacetic acid is involved in these processes.

The activation of P53 by Antineoplaston AS2-1 probably occurs in hepatocellular carcinoma cells. Liau demonstrated that Antineoplaston AS2-1 converted the cancer methylation enzyme which is 7 times more active than normal to the normal enzyme, which would lead to the relative hypomethylation of nucleic acids and could change gene expression. Those speculations should be confirmed by direct evidence in future studies.

The continuous oral administration of Antineoplaston AS2-1 8-10 g/day in our patient induced gradual disappearance of the viable part of the tumor and no metastases of HCC was seen on dynamic CT taken at 13 and 20 months. Considering that most of HCC patients who have had TAE with HCC of this size develop recurrence and intrahepatic multiple metastases within a year, the dynamic CT findings in this particular patient would suggest that the viable tumor tissue around the incompletely embolized area first became stable and then disappeared after Antineoplaston AS2-1 administration. This clinical picture seems to be consistent with results of our in vitro study of Antineoplaston AS2-1. This patient has been working without any limitations on his normal activity, except when he was admitted to the hospital for TAE, PEIT for a short period. 
Since HCC patients have underlying liver dysfunction, chemotherapy for recurrence or multiple intrahepatic metastases often leads to a miserable outcome. To improve treatment after the early detection of $\mathrm{HCC}$, a less toxic antineoplastic and antitumorigenic approach should be developed. From this point of view, Antineoplaston AS2-1 appears to be one of the best candidates of drug for the treatment of HCC.

To summarize, we found that Antineoplaston A10 and AS2-1 exhibited an inhibitory effect on cell proliferation in 6 HCC cell lines, and both agents increasing the cell population in $G_{0}$ and $G_{1}$ phases. Antineoplaston AS2-1 induced apoptosis in HCC cells.

We also described the clinical case of a HCC patient who showed the gradual disappearance of a viable tumor lesion in 13 and 20 months after the beginning of Antineoplaston AS2-1 treatment.

\section{References}

Burzynski SR. Antineoplastons; Biochemical defense against cancer. Physiol Chem Phys 1976; 8:275-279.

Burzynski SR, and Hai TT. Antineoplaston A10. Drugs of the Future 1985; 10:103-105.

Burzynski SR, Mohabbat MO, and Lee SS. Preclinical studies of Antineoplaston AS2-1 and Antineoplaston AS2-5. Drugs Exp Clin Res 1986 (Suppl); 1:25-28.

Eriguchi N, Hara H, Yoshida H, Nishida H, Nakayama $\mathrm{T}$ et al. Chemopreventive effect of Antineoplaston A10 on Urethane-induced pulmonary neoplasia in mice. J Jpn Soc Cancer Ther 1988; 23 (7):1560-1565.

Hendry LB, Muldoon TG, Burzynski SR, Copland JA, and Lerner AF. Stereochemical modelling studies of the interaction of
Antineoplaston A10 with DNA. Drugs Exp Clin Res 1987 (Suppl); 1:77-81.

Ikeda K, Kumada H, Saitoh S, Arase Y, and Chayama K. Effect of repeated transcatheter arterial embolization on the survival time in patients with hepatocellular carcinoma: An analysis by Cox proportional hazard model. Cancer 1991; 68:2150-2154.

Liau MC, and Burzynski SR. Altered methylation complex isozymes as selective targets for cancer chemotherapy. Drugs Exp Clin Res 1986 (Suppl); 1:77-86.

Muldoon TG, Copland JA, and Hendry LB. Actions of Antineoplaston A10 on the genesis and maintenance of specific subpopulations of rodent mammary tumor cells. Advances in Experimental and Clinical Chemotherapy 1988; 1:15-18.

Nakao N, Kamino K, Miura K, Hayashi T, Ohnishi $\mathrm{M}$ et al. Recurrent hepatocellular carcinoma after partial hepatectomy: value of treatment with transcatheter arterial chemoembolization. Amer $\mathrm{J}$ of Radiology 1991; 156:1177-1179.

Nishida H, Yoshida H, Eriguchi N, Hoshino K, Kubota $\mathrm{H}$ et al. Inhibitory effect of orally administered Antineoplaston A10 on the growth curve of human breast cancer transplanted to athymic mice. J Jpn Soc Cancer Ther 1991; 26:596-601.

Okuda K, Fujimoto I, Hanai I, and Urano Y. Changing incidence of hepatocellular carcinoma in Japan. Cancer Res 1987; 47:49674972.

Samid D, Yeh T-J and Shack S. Interferon in combination with antitumorigenic phenylderivatives; potentiation of INF alpha activity in vitro. Br J Haematol 1991; 79 (Suppl) 1:81-83.

Samid D, Shack S, and Sherman LT. Phenylacetate: A novel nontoxic inducer of tumor cell differentiation. Cancer Research 1992; 52:1988-1992.

Tanaka S, Kitamura T, Nakanishi K, Okada S, Yamazaki $\mathrm{H}$ et al. Effectiveness of periodic checkup by ultrasonography for the early diagnosis of hepatocellular carcinoma. Cancer 1990; 66:2210-2214. 
Unoura M, Kaneko S, Matsushita E, Shimoda A, Takeuchi $\mathrm{S}$ et al. High risk groups and screening strategies for early detection of hepatocellular carcinoma in patients with chronic liver disease. Hepatogastroenterology. 1993; 40:305-310. 